\title{
腎盂尿管癌の手術治療におけるリンパ節郭清
}

\author{
栃木県立がんセンター泌尿器科（中溒昌明部長） \\ 中薗昌明村木 淳 郎
}

\section{LYMPHADENECTOMY IN THE OPERATIVE TREATMENT OF RENAL PELVIC AND URETERAL CARCINOMA}

\author{
Masaaki Nakazono and Junrou Muraki \\ Department of Urology, Tochigi Cancer Center
}

We evaluated 18 patients with renal pelvic and ureteral carcinoma focusing on the operative treatment. All the patients underwent nephroureterectomy and partial cystecotomy, except for two patients, with CIS of the ureter and renal insufficiency, and one with invasive bladder carcinoma, in whom partial ureterectomy and total cystectomy were performed, respectively. Lymphadenectomy were performed in all the patients and resected lymph nodes were from renal hilus, para-aorta or vena cava, according to the affected side, intra aorto-caval and all the pelvic nodes in the affected side. Lymph node metastases were found in 4 patients (22\%), 2 in the primary and distant nodes and the other in the regional nodes only. Skipped lesion of the lymph node metastasis was not rare and lymph node dissection from the renal hilus to the pelvis on the affected side should be included in the operative treatment of renal and ureteral carcinoma.

Key words: renal pelvic and ureteral carcinoma, lymphadenectomy, operative treatment

\begin{abstract}
要旨：手術治療に焦点を置いて，我々の経験した腎孟尿管癌18症例について検討した。腎不全を伴った 尿管 CIS 症例之膀胱癌同時発生例で浸潤癌であった 2 症例をのぞいて全例に腎尿管全摘術おょび膀脱 部分切除術を行った。腎不全例には尿管部分切除術のみ施行し腎は保存した。 また膀胱浸潤癌症例は膀 胱全摘出術を行った。リンパ節郭清を全例に行い, 郭清範囲を患側腎茎部, 傍大動脈又は傍大静脈, 大 動静脈間リンパ節, さらに総腸骨, 内腸骨, 外腸骨リンパ節および閉鎖節とした。リンパ節転移を 4 症 例 (22\%) に認め，2 症例は原発巣に近接したリンパ節に認めたが， 2 症例はいわゆる skipped lesion であった. Skipped lesion は稀な現象ではなく, 手術治療の面より考えれば今回行ったリンパ節郭清は 必要な手術操作と考えた。
\end{abstract}

キーワード：腎孟尿管癌, リンパ節郭清, 手術手技

$\mathrm{M}-\mathrm{VAC}$ 療法を始めとして種々の多剤併用化学療法 が転移性移行上皮癌に試みられているが満足のいくも のとはなっていない. 膀胼癌や腎㙉尿管癌の最も効果 的な治療は手術療法であり原発巣の完全な切除とリン パ節の郭清である。したがって手術手技の選択は症例 に応じて慎重に決定しなければならない，腎孟尿管癌 の原発巣切除術として腎尿管全摘および膀胱部分切除 を行っている施設が多い(12)。 しかし，一方では腎部分 切除術 ${ }^{344)}$ や内視鏡下に腫瘍切除を行う縮小手術によ る成績も発表されるなど新しい方向が模索されてい る(5) . リンパ節郭清に関しては定見がみられず, 原発 巣の発生部位によって切除範囲を限定して行っている
施設や症例に応じて適応を決定している施設などがあ $3^{9) \sim 12)}$. また両側同時発生例や経過観察中の対側腎や 尿管再発の治療をどのよらにしたら良いのか等, 今後 の検討を要する問題である. 栃木県立がんセンターで 手術療法を行った 18 症例について外科的治療を中心に 検討し興味ある結果をえたので報告する。

\section{対象と方法}

1986年 9 月より1991年12月までに栃木県立がんセン ターで手術治療を行った腎孟尿管癌18症例を対象とし た。年齢分布は 57 86 歳, 平均年齢は 71.8 歳で男女は 10：8であった。組織型は全例移行上皮癌で異型度は G3：8 例, G2 : 7 例, G1：3 例で左右は右 11 例, 左 6 
図 1 A : 右腎賈尿管癌のリンパ節郭清範囲, B : 左側の郭清範囲

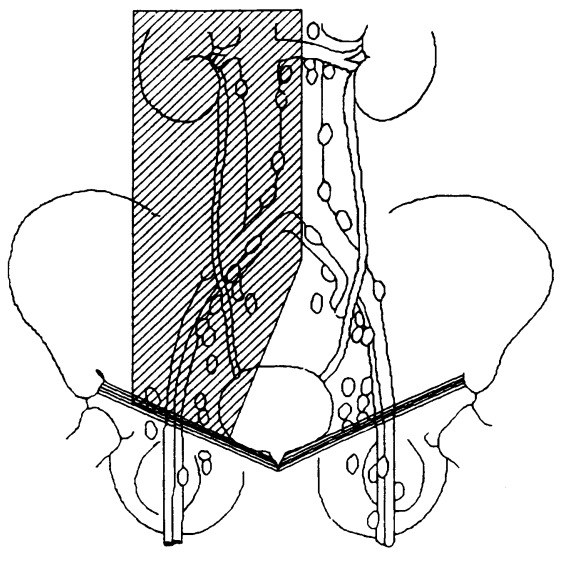

A

例，両側 1 例であった，発生部位は右腎孟 4 例，右尿 管 6 例(上部 1 例, 中部 2 例, 下部 3 例, 左腎孟 1 例, 左尿管 3 例(中部 1 例, 下部 2 例), 両側下部尿管抢よ び膀脱 1 例, 左腎孟および膀脱 1 例, 左腎孟・尿管全 域および膀脱 2 例であった。

手術手技は全例，剣状突起肋骨角より恥骨結合上縁 までの腹部正中線切開にて腹腔内に入り，右側は十二 指腸の右外側に沿って壁側腹膜を切開し,さらに右横 隔膜結腸勒帯および上行結腸の外側の腹膜を切開し上 行結腸, 横行結腸の右側を下内方に圧排し, 後腹膜腔 を露出した。腹部大静脈を確認した後，右腎動静脈を 周囲組織より剝離し結紮処理した。

左側は脾結腸勒帯および左横隔膜結腸勒帯を切開 し，さらに下行結腸外側で壁側腹膜を切開し下行結腸 を内側下方に圧排し後腹膜腔に達した，尿管は膀胱壁 の一部を含めて全摘した。腎機能の低下した左尿管 CIS 症例は左尿管の中部下部を切除し，遊離回腸によ る interpositionにより尿管を再建し, 左腎は保存し た。

左腎孟尿管全域および膀胱の同時発生例， 2 例の中 1 例は膀胼浸潤癌であったため膀脱全摘を行い, 右尿 管は tubeless 尿管皮膚瘦術を行った。両側同時発生例 は, 右腎, 尿管全摘と膀胼部分切除を行い, 左尿管 CIS は BCG の腎孟尿管灌流療法を行った。

リンパ節郭清の範囲は患者の腎茎部，傍大動脈又は 傍大静脈リンパ節，大動静脈間リンパ節，および患側 の総腸骨，内腸骨，外腸骨リンパ節，閉鎖節とした。 右側の腎茎部より上部のリンパ節は右副腎剝離の際, 腎静脈起始部より横隔膜までの大静脈右側壁部分のみ

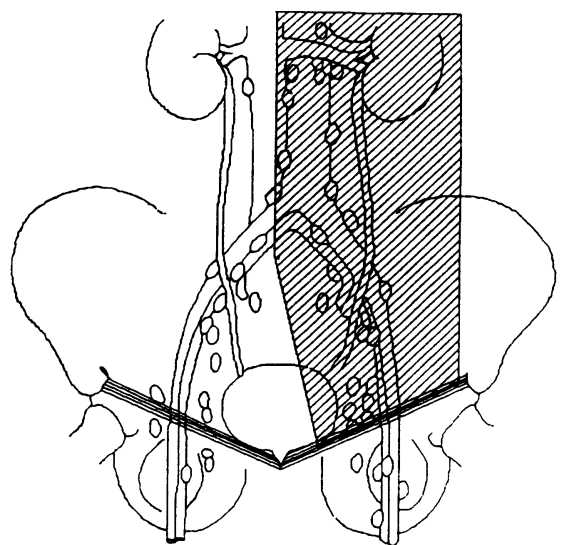

B

切除した。左側は上腸間膜動脈の下部より大動脈側壁 に沿って大動脈分岐部まで切除し傍大動脈リンパ節と した。 大動静脈間リンパ節は腎動脈の下縁より下腸間 膜動脈の起始部まで切除した。下腸間膜動脈は保存し た。骨盤内リンパ節は総腸骨, 外腸骨, 内腸骨リンパ 節閉鎖節の順に切除した。腎茎部より横隔膜までの大 動脈前壁, 大動静脈間リンパ節は膵頭部を脱転する必 要があり技術的にも困難なため行っていない，椎体動 静脈の処理は血管の起始部と血管が椎体内に進入する 所の 2 カ所で結紮処理した. 特に静脈の処理を慎重に 行い, 出血の防止に留意した。 リンパ節郭清の範囲を 図 1 に示した。

\section{結 果}

遠隔転移を有する症例はなく全例治癒切除と判定し た.リンパ節郭清に伴ら重篤な合併症は認められな かった。ただ 2 症例に 2 週間にわたる lymphorrhea と 低蛋白血症が認められたが，いずれも対症療法で軽快 した。 18 症例中 4 例 $(22 \%)$ に組織学的に移行上皮癌 を確認しリンパ節転移と判定した。

転移がみられたのは腎孟癌 1 例，および総腸骨動脈 交差部以下の下部尿管癌の 3 例であった．腎孟癌症例 と尿管癌症例の 1 例は原発巣に隣接したリンパ節転移 であったが，他の尿管癌 2 例は傍大動脈，傍大動脈リ ンパ節にも転移がみられた。この中の 1 例は対側総腸 骨リンパ節および内腸骨リンパ節にも転移が認められ た，尿管癌 3 例の異型度はすべて G3で腎孟癌は G2で あった。尿管癌の深達度は pT2，1 例，pT3，2 例で， 腎孟癌は $\mathrm{pT} 1$ であった。 4 転移例の中，尿管癌の 1 例 は脺尾部癌を併発し死亡したが，他の 3 例は郭清後 5 
困 2 腎孟尿管癌18症例の生存率

\section{Survival rate of Upper urinary tract TCC}

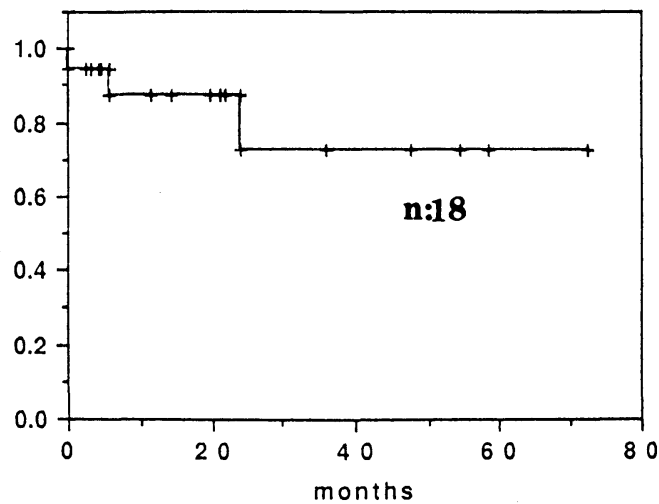

図 3 腎靁尿管癌の非再発率

Recurrence free rate of Upper urinary tract TCC

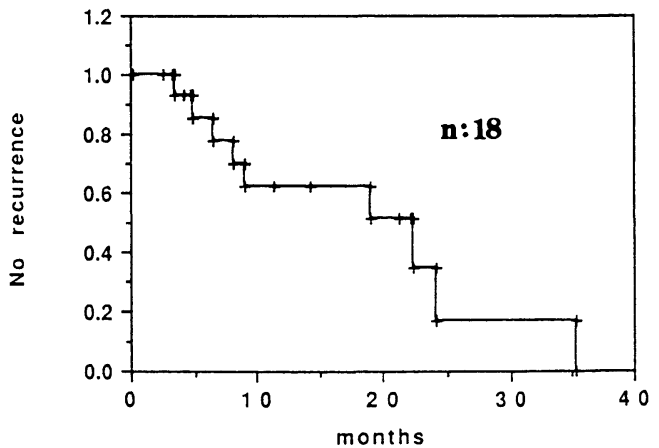

年11力月, 4 年11力月, 1 年11力月癌なし生存してい る. 7 例に膀脱癌の続発を認め全例 TUR-Bt 後 BCG 膀脱内注入療法を行い再発予防としたが，1例に尿道 と膀脱に再発し膀脱尿道全摘術を行った。 またTURBt 3 年後に浸潤性膀胱癌を発生した 1 例は膀脱部分 切除術を行い後療法として放射線治療を追加した。初 回治療後 2 年 6 力月に対側尿管の中部々下部にCIS を発生した症例は，尿管部分切除を行い，遊離回腸に よる尿管再建術を行った。術後 1 年癌なし生存してい る. 死亡例は 3 例で, 癌死 1 例, 手術直接死亡 1 例, 他因死 1 例である.手術直接死亡例は術後 3 日目に心 筋梗塞を併発し死亡した。

今回の検討では原発巣治療後 37 月以上の非再発期 間がえられた症例はなく，早期より膀胖を中心に再発 がみられた。図 2 に生存率を図 3 に非再発率を示した。 両者とも Kaplan-Meier 法により算出した。
図 4 症例 1 , 男, 86歳. 右腎孟癌 pT1であるが腎茎 部リンパ節転移を認めた. $\mathrm{P}$ ：原発巣, $\mathrm{M}$ ：リンパ節 転移

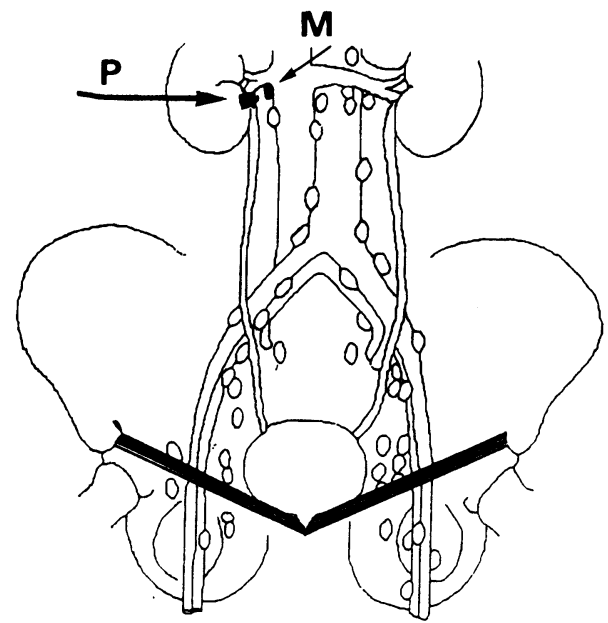

図 5 症例 2 , 女, 76歳, 左下部尿管癌, pT3, 外腸骨 リンパ節転移を認めた， $\mathrm{P}$ : 原発巣, $\mathrm{M}$ ：リンパ節転 移.

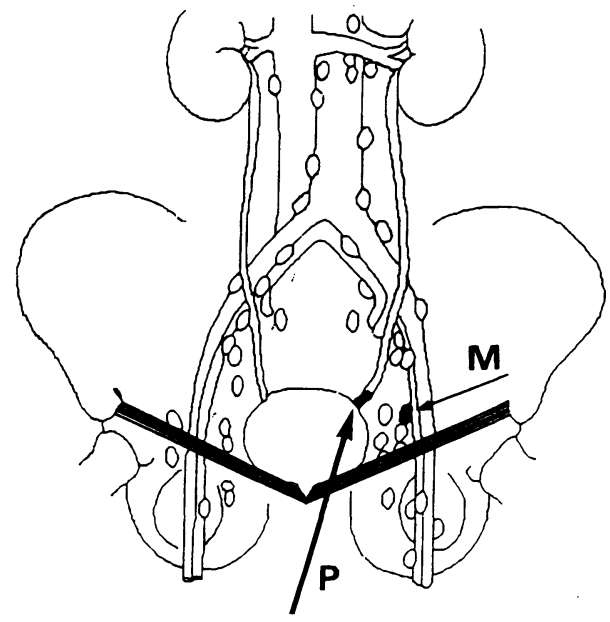

症例

症例 1 ：S.Y. 男, 86歳

右腎血癌, 移行上皮癌 $\mathrm{G} 2, \mathrm{pT} 1 \mathrm{pN} 1 \mathrm{M} 0$, 患側腎茎部 リンパ節転移を認めた。腎尿管全摘術および膀脱部分 切除術を施行後 3 年浸潤性膀脱癌を発生したため, 膀 胼部分切除術と後療法として放射線治療を行った。初 回治療後 5 年11力月の現在癌なし生存している（図 4 ).

症例 $2 ：$ T.T. 女, 76 歳

左下部尿管癌, 移行上皮癌 G3>G2, pT3pN1M0, 
図 6 症例 3 , 女, 66歳, 右下部㽷管癌 $\mathrm{pT} 2$, 肉眼的に 傍大動脈, 傍大静脈, 両側内腸骨リンパ節の腫大が みられた。組織学的にリンパ節転移（M) を確認し た $(\mathrm{n} 7 / 20)$. 術後 2 年, 左腎茥部リンパ節転移 $(\mathrm{m})$ を認めた。 5 年11力月後癌なし生存している。

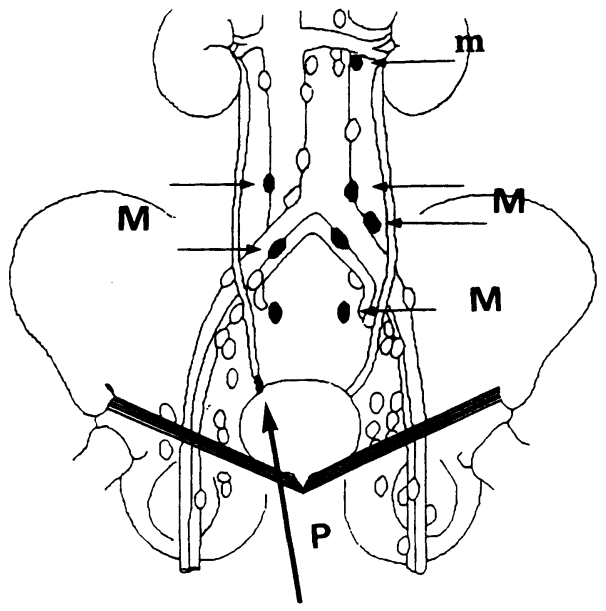

図 7 症例 4 , 男, 63歳. 右下部尿管癌 $\mathrm{pT} 3$, 傍大動 脈，傍大静脈リンパ節転移を認めた $(\mathrm{n} 3 / 15) .1$ 年11 カ月後癌なし生存している. $\mathrm{P}$ : 原発巣, $\mathrm{M}$ ：リンパ 節転移

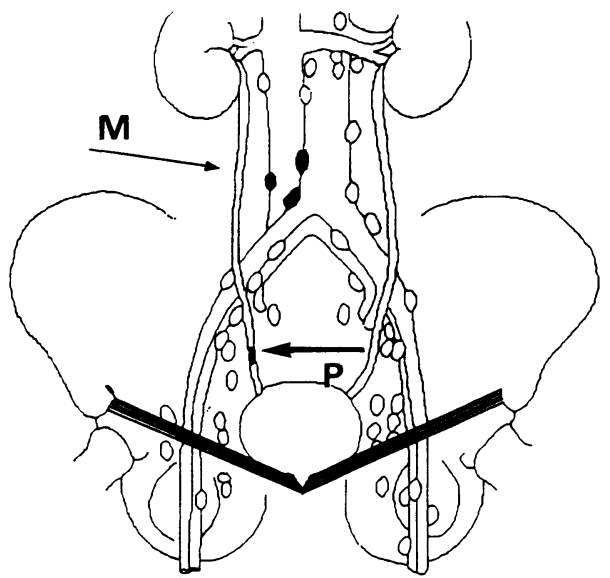

患側外腸骨リンパ節に転移を認めた，膵尾部癌を合併 し 2 年後膵癌全身転移のため癌死した。剖検にて膀胱 癌（移行上皮癌 $\mathrm{G} 2>\mathrm{G} 3, \mathrm{pT} 1 \mathrm{a}$ ）を認めた（図 5 ）.

\section{症例 3 : K.I. 女, 66歳}

右下部尿管癌, 移行上皮癌 G2>G3，pT2pN2M0， 肉眼的に傍大動脈リンパ節，両側総腸骨リンパ節の腫 大を認めたため, 左総腸骨, 外腸骨, 内腸骨リンパ節 の郭清を追加した。傍大静脈リンパ節, 両側内腸骨リ
ソパ節に転移を認めた。術後 2 年, 左腎茥部リンパ節 の腫大を認め, 郭清し, 転移を確認した。補助療法と して M-VAC 療法を合計 4 コース施行した。初回治療 後 5 年11力月癌なし生存している。転移巣の分布を図 6 に示した。

症例 4 : M.H. 男, 63歳

右下部尿管癌，移行上皮癌 $\mathrm{G} 3>\mathrm{G} 2, \mathrm{pT} 3 \mathrm{pN} 2 \mathrm{M} 0$, 傍大静脈，大動静脈間リンパ節に転移を認めた。骨盤 内リンパ節には転移を認めなかった。後療法として $\mathrm{M}-\mathrm{VAC}$ 療法を 3 コース行った. 現在術後 1 年 11 月 癌なし生存している（図 5 ).

\section{考察}

腎血尿管癌のリンパ節転移は $14 \%$ 程度とするものか ら40\%を超えたとするものまで種々の報告があるが， 転移陽性例の 5 年生存率は $0 \sim 25 \%$ と極端に悪い。こ れに対し転移を認めなかった症例のそれは70〜80\%と 良好な成績が報告されている ${ }^{13) \sim 15)}$. 日本泌尿器科学 会, 日本病理学会編集の腎衁尿管癌取り扱い規約 ${ }^{16)}$ で はリンパ節郭清に関し下記の 5 項に分類している.

1）施行せず.

2）生検のみ：転移の疑われるリンパ節のみ郭清す る.

3）限局郭清：膀胱発生部位に近接するリンパ節の 又郭清した場合。

4）広汎郭清：患側の所属リンパ節すべてを郭清し た場合.

5）その他：その他の部位のリンパ節を郭清した場 合.

また，リンパ節を以下の 4 つに分類している。

1）上部リンパ節：横隔膜より腎動静脈の上縁まで。

2）中部リンパ節：腎動静脈下縁より下腸間膜動脈 起始部まで。

3）下部リンパ節：下腸間膜動脈起始部より大動脈 分岐まで。

4）骨盤内リンパ節：膀胱癌取り扱い規約に準ずる. としている.問題になるのは原発巣の部位や病期に よってこの分類をどのように活用したら良いのかが示 されていないことである、すなわち, 病期, 発生部位 によってリンパ節郭清範囲を限定して行って良いの か, 限定するとすればどのような基準に基ついて行っ たら良いのか明確でない。また患側リンパ節の定義が 明確にされていないので今日まで発表されている論文 にしばしば使用されている『患側リンパ節を郭清』し たという記述はどの範囲を意味するのか不明である。 
たとえば右腎孟の患側リンパ節として右腎茎部, 傍 大静脈リンパ節は当然ふくをれるが，大動静脈間リン パ節は含まれるのか否か, 傍大動脈リンパ節はまった く含めないのか判然としない。また傍大動脈リンパ節 の上限，下限をどのように規定したのかも不明である。 発生部位に関しても明確な規定がなされていない。確 かに腎孟尿管のリンパ流が明らかにされていない現 在, 理論的根拠を持った腫瘍発生部位に関連したリン パ節郭清範囲を決定するのは困難である。

岡野らつはリンパ節郭清の範囲を原発巣の部位に 従って腎孟, 上部尿管腫瘍の場合は同側の腎茎部, 傍 大動脈または傍大静脈リンパ節を，また下部尿管腫瘍 では同側の骨盤内リンパ節を郭清することを原則とし た 34 症例の結果を報告している. 34症例中15例 (44.1\%)にリンパ節転移を認めている。転移部位は腎 茎部および傍大動静脈リンパ節が主体で，いわゆる skipped lesionは認められなかったと報告している。

しかし, 我々の経験は症例数が18症例と少ないが, 4 症例にリンパ節転移を認め, 2 症例は腫瘍発生部位 に近接していたが, 2 症例は skipped lesion の形態を 取っていたことは注目された。文献的にも skipped lesion の存在に否定的であることもあって, 今回我々 の行った腎茎部より骨盤腔内にいたるリンパ節郭清は 広範囲にすぎるのではないかと考えたが，現実には広 範囲に転移リンパ節が散在していたことを確認しえる 結果となった。

リンパ節郭清に伴ら重篤な合併症はみられず, lymphorrhea と低蛋白血症を呈した 2 症例は対症療 法で軽快している。リンパ節郭清は予後を予測する重 要な要素の 1 つであるが, 予後の改善にはならないと されているが9113)，リンパ節転移症例の予後の改善の 一助として広範囲に郭清し, 転移の形態をすこしでも 詳細に理解することに意義があると考えた。

我々は転移症例に積極的に M-VAC 療法等による 後療法を行い, 予後の改善を図る必要があると考兄て いる，安全に広範囲の郭清を行らためには，十分広い 手術野がえられなければならない，我々は手術手技の 項で述べたように原発巣の局在に関係なく剣状突起肋 骨角より恥骨結合上縁に至る正中線切開で腹腔内に入 り, 上行結腸か, 下行結腸の外側縁で壁側腹膜を切開 し結腸を内側に圧排し, 後腹膜腔を展開し, 安全な手 術が施行しえる広い視野をえた。

膀脱部分切除に関しては, Gittes ${ }^{18)}$ が主張している ように尿管組織の完全切除を目的としているのである
から切除標本を術中に検討し完全切除がなされている こと確認することが重要と考えている.

腎孟尿管癌では膀胱癌の続発が高頻度にみられるこ とは良く知られているが(19) 21), 対側腎や尿管の発生は 少ないとされている ${ }^{13)}$. しかし今回の検討でも両側尿 管同時発生 1 例, 対側尿管の CIS 発生 1 例がみられた ように両側腎孟尿管が罹患する割合は必ずしも低いも のではないと思われた 2223). このような外科治療の困 難な症例に対し BCG の腎孟尿管灌流が試みられ良い 成績が報告されている24)25). しかし BCG の膀脱内注 入療法に伴う萎縮性変化, 肉芽形成などを考慮すると BCG 療法が対側発生の治療法の第一義的な子のには なりえない. 今後の大きな課題の 1 つである ${ }^{26) 27)}$.

\section{結 語}

栃木県立がんセンターで手術治療を行った腎孟尿管 癌18症例について, 外科的治療, 特にリンパ節郭清の 範囲，手技およびその意義について検討した。 また対 側尿管再発など両側発生例に関し私見を述べた。

\section{文献}

1) Johansson, S., Angervall, L., Bengtsson, U. and Wahlqvist, L.: A clinicopathological and prognostic study of epithelial tumors of the renal pelvis. Cancer, 37, 1376-1383, 1976.

2) Johansson, S. and Wahlqvist, L.: A prognostic study of renal pelvic tumors. Cancer, 43, 2525-2531, 1979.

3) Vest, S.A.; Conservative surgery in certain benign tumors of the ureter. J. Urol., 53, 97-121, 1945.

4) Ziegelbaum, M., Novic, A.C., Streems, S.B., Motie, J.E., Pontes, J.E. and Straffon, R.F.: Conservative surgery for transitional cell carcinoma of the renal pelvis. J. Urol., 138, 1146-1149, 1987.

5) Marshall, F.F. and Walsh, P.C.: In situ management of renal tumors : Renal cell carcinoma and transitional cell carcinoma. J. Urol., 131, 1045-1049, 1984.

6) Huffman, J.L., Baglev, D.H., Lyon, E.S., Morse, M.J., Herr, H.W. and Whitmore, W.F. Jr. : Endoscopic diagnosis and treatment of upper urothelial tumors: A preliminary report. Cancer, 55, 1422-1428, 1985.

7) Woodhouse, C.R.T., Kellett, M.J. and Bloom, H. J.G.: Percutaneous renal surgery and local radiotherapy in the management of renal pelvic transitional cell carcinoma. Br. J. Urol., 58, 245-249, 1986. 
8) Streem, S.B. and Pontes, E.J.: Percutaneous management of upper tract transitional cell carcinoma. J. Urol., 135, 773-775, 1985.

9) Grabstald, H., Whitmore, E.F. and Melamed, M. R. ; Renal pelvic tumors. J.A.M.A., 218, 845-854, 1971.

10) Batata, M.R., Whitmore, R.F. Jr., Hilaris, B.S., Tokita, N. and Grabstald, H.: Priamry carcinoma of the ureter : A prognostic study. Cancer, 35, 1626-1632, 1975.

11）滝花義男, 田辺信明, 小林克己, 小松秀樹, 上野 精：尿路腫瘍 PN1の 1 症例とリンパ節郭清の意 義について. 日泌尿会誌, 78, 1618-1620, 1987.

12) Catalona, W.J.: Surgical study of genitourinary tumors. Cancer, 60, 459-463, 1987.

13) Droller, M.J.: Transitional cell cancer of the renal pelvis and ureter. in Walsh, P.C., Gittes, R. F., Permutter, A. and Stamey, T.A. (Eds.) : Cambell's Urology. Philaderphia, W.B. Saunders, Co., 1986, p. 1421.

14）田代和也, 鳥居伸一郎, 岩室伸也, 町田豊平, 増田 富士男, 大石章彦, 上田正山, 望月 篤, 浅野晃己, 木夫 晃, 和田鉄郎, 吉越富久夫 : 腎盂尿管癌の臨 床的病態と予後の検討. 日泌尿会誌, 81, 439-446, 1990 .

15）横山正夫, 河合弘二, 東海林文夫, 柳沢良三, 金村 三樹郎, 北原 研, 藤戸収作 : 腎孟尿管腫瘍 50 例 の遠隔成績. 日泌尿会誌, 81，1031-1038，1990.

16）泌尿器科・病理・腎典・㽷管取り扱い規約, 日本泌 尿器科学会, 日本病理学会編, 金原出版, 東京, 1990.

17）岡野達弥, 井坂茂夫, 阿部功一, 五十嵐辰男, 木村 信乃, 松蒡 理, 島崎 淳: 腎衁尿管癌に対する節 郭清の検討. 日泌尿会誌，82，816-820，1991.

18) Gittes, R.F.; Tumors of the bladder. in Harrison, J.H., Gittes, R.F., Perlmutter, A., Stamey, T.A. and Walsh, P.C. (Eds.) : Cambell's Urology.
Philaderlphia, W.B. Saunders, Co., 1971, p. 1033.

19）田代和也, 古田 希, 岩室伸也, 小針俊彦, 浅野晃 司, 中内憲二, 長谷川倫男, 和田鉄郎, 大石章彦, 町田豊平：腎孟㽷管癌に併発する膀胱癌の臨床的 意義. 日泌尿会誌, 82,1771-1775，1991.

20) Kakizoe, T., Fujita, J., Murase, T., Matsumoto, K. and Kishi, K. : Transitional cell carcinoma of the bladder in patients with renal pelvic and ureteral cancer. J. UROL., 124, 17-19, 1980.

21) Williams, C.B. and Mitchell, J.P.: Carcinoma of renal pelvis: A review of 54 cases. $\mathrm{Br}$. J. UROL., 45, 370-376, 1973.

22) Mills, C. and Vaughan, E.D.J. : Carcinoma of ureter: Natural history, management and 5year survival. J. Urol., 129, 275-277, 1983.

23) Cummings, K.H. : Nephroureterectomy : Rational in the management of transitional cell carcinoma of the upper uriary tract. Urol. Clin. N. Amer., 7, 569-578, 1980.

24) Herr, H.W.; Durable response of a carcinoma in situ of the renal pelvis to topical bacillus Calmette-Guerin. J. Urol., 134, 531-532, 1985.

25) Studer, U.E., Casanova, G., Kraft, R. and Zing, E.J.: Percutaneous bacillus Calmette-Guerin perfusin of the upper urinary tract for carcinoma in situ. J. Urol., 142, 975-977, 1989.

26) Huffman, J.L., Morse, M.J., Herr, H.W. and Whitmore, W.F.Jr.: Consideration for treatment of upper uriary tumors with topical therapy. Urology, 26, 47-50, 1985.

27) Nissenkorn, I., Servadio, C., Vilikowski, E. and Glanz, I.: Longterm intravesical thiotepa treatment in patients with superficial bladder tumors and vesicoureteral reflux. J. Urol., 133, 198-199, 1985.

（1992年10月20日受理） 